\title{
The University Student Voices on Online Language Classes during Covid-19 Pandemic in Indonesia
}

\author{
Teresa Angelina Kaluge
}

\author{
Department of Japanese Studies, Airlangga University, Surabaya, Indonesia \\ Email: teresa.angelina.k@fib.unair.ac.id
}

\begin{abstract}
Covid-19 pandemic outbreak happened in the beginning of the year 2020 but learning should be done on purpose based on the course outline. This study aimed to find out students' voices according the effect of switching Japanese Kanji and grammar course to online courses during the pandemic. The courses delivered using university's online platform and WhatsApp Group. Using Google Forms, a semi open questionnaire was delivered to all respondents. The sample consisted of 136 students of a state university in Surabaya, ranged from semester two to twelve. Students responses were analysed descriptively. Most of the respondents expressed that online learning from home is comfortable, and easy to follow. However, there were some precautions about unstable signal during the course, difficulty in finding comfortable places outside home and campus, and prompt feedback from lecturer may affected their motivation to be actively involved. The results to give reference on how to improve online teaching in higher education level in the future.
\end{abstract}

Keywords: Learning environment, learning tools, online teaching, student voice

\section{INTRODUCTION}

The Corona virus (Covid) pandemic is thought to have taken place at the end of 2019 in Wuhan, China and spread throughout the world, including Indonesia, since early 2020. To prevent the virus spread, official government institutions, including BNPB (2020) issued an official letter banning the gathering of many people in one place, and introducing several health protocols.

In the education sector, the Mendikbur (2020) or Ministry of Education, issued official circulars for all levels of education to turn face-to-face meetings into online learning. Undoubtedly, this sudden change could result in some components of the traditional class to change, or even disappear. Previous studies relating to education during the corona virus pandemic in Indonesia mostly examined the point of view of educational practitioners, such as teachers and lecturers (Atmojo \& Nugroho, 2020; Windhiyana, 2020). Studies that discussed student perceptions, which conducted by Cakrawati (2017), so far have only been carried out in normal situations, not during this pandemic. Although teachers' and lecturers' perceptions are of course very important, we cannot ignore the opinions of students who are the recipients of teaching material. Looking further, what motivate and demotivate students to join the courses in online mode in a state university? Students may have taken the online classes before, for just a few meetings, but what do they think about if they have to take online classes for quite a long time and this applies to all the courses they take? This study attempts to answer these questions.

\section{LITERATURE REVIEW}

Teaching online classes in normal situations is not the same as during a pandemic (Gacs, Goetler, \& Spasova, 2020). In a normal situation, generally, the material has been prepared from the very beginning, while during a pandemic, the class becomes online due to an emergency situation, resulting in both lecturers and students being unprepared. Lecturers also have to undergo extra work in changing the format of the material that has been prepared beforehand, to the form that suits the online class while at the same time, thinking of the best way to present it to their students.

Psychologically, in facing changes, a person will show two optional attitudes, resistance or acceptance. One of the main factors of resistance, is due to concern that the changes occurred might be uncontrollable, and for another reason is because of the extra work required 
in doing things for transitioning the changes (Oreg, 2003). The second attitude, however, is to accept changes enthusiastically. Wanberg and Banas (2000) describe some of the reasons as optimism, and the ability to control oneself. In the pandemic situation, both teachers and students are vulnerable to rejection or acceptance of distance learning policies. We cannot underestimate this aspect, because it could impact their performance during online classes.

In Indonesia, research on the opinions of teaching and learning activities during the pandemic has been reviewed by Atmojo and Nugroho (2020) and Windhiyana (2020). The opinions of the teachers in the middle school environment were reviewed by Atmojo \& Nugroho (2020) with the main results both teachers and students experiencing difficulties. The reason was because online classes happened suddenly, without their own volition, and they were not ready yet for these changes. Both students and teachers were in different locations with unequal signal strength, so some students could not attend classes due to their poor internet connection (Atmojo \& Nugroho, 2020). This was especially happened when they used Zoom and some students were experiencing problems because basically, they could not operate the device properly and correctly. Another study by Windhiyana (2020) examined the opinions of students and lecturers who had to take online classes at a private university in Central Java. In this study, both parties felt that the online class was comfortable, even though there were internet connection problems when doing discussion via Zoom. The problem was solved because the lecturer was willing to explain the material again.

Study that specifically examines the voices of higher students in Indonesia has not been done much. A previous study that examined this aspect was conducted on English online classes (Cakrawati, 2017), but in normal situations, not during pandemics. The results showed that students considered the online classes as effective and can improve their ability to use foreign languages.

In accordance to the results from previous studies on the teacher and student perceptions, this study aims to examine more on how students think of online classes that were held suddenly and simultaneously for the long period of time, if some things are motivating or might be demotivating for them. All courses have been changed to online, but lecturers certainly have the freedom to develop teaching materials and to deliver the materials according to their respective abilities. Thus, the delivery of material on courses can be very different from one to another, because it was conducted by different lecturers. To control this difference, this study will only examine the courses taught by the researcher.

\section{METHODS}

This study was a qualitative inquiry where 'voice' was the main attention instead of perception or attitudes. The term of voice was characterized as present, selfreflective, authentic, and stable (Marker, 2003; Mazzei, 2009). This study was carried out in Airlangga University, a state higher institution located in Surabaya. The participants were 136 students (58\% female an $42 \%$ male) who participated from three different online courses, namely Chūky $\bar{u}$ Nihongo (Intermediate Japanese Grammar), Chūky $\bar{u}$ Kanji (Intermediate Japanese Kanji), and Kanji Nyūmon (Introduction to Japanese Kanji). The three different courses were picked up due to the convenience, all delivered with the same pattern, namely material, task collection and weekly quizzes were undergone through the university online platform called AULA. In addition, the students and lecturer interactions (question and answer sessions, and discussions) were performed via the WhatsApp group. Thus, the evaluation results from students were valid for the same implementation patterns. Each course had a questionnaire with the same format, consisting of 12 open questions that probing the students on biographical data, how they access lectures, and what they thought about the course being taught. They were all students of semester two to twelve. Questionnaires consisted of open questions were distributed to the students by using the form of Google Forms. At the time the questionnaire was distributed, all online meetings had just been completed, and students were in a quiet week welcoming the final semester exams. So, their answers were purely on how they thought and felt of the whole online lectures until it had been completed.

\section{FINDINGS AND DISCUSSION}

The results showed that the majority of students took lectures from outside Surabaya (58.8\%) and almost all respondents took online classes from their respective homes $(94.9 \%)$. The $4.4 \%$ students attended lectures from outside their home. The places varied from café, internet café, mosques, libraries, to relatives' house. They answered that the internet connection at home was very bad, so they had to leave, and even reaching their relatives' home. Unstable connections were actually not a new problem, because this was commonly experienced in lectures and online school classes (Atmojo \& Nugroho, 2020; Windhiyana, 2020).

For media used during online lectures, some students used laptops / computers (13.2\%), smartphones / mobile phones (20.6\%) and most of them used both $(66.2 \%)$. This finding was understandable, considering the use of smartphones was more practical, more integrated with real time, and more personal than computers (Guillén, Sawin, \& Avineri, 2020). 
Then, for the surrounding environment during the online lecture, majority of students felt comfortable with the environment $(57.4 \%)$, some considered the environment as too noisy (33.8\%) and the rest answered the environment was too quiet $(8.8 \%)$. The environment was very influential, especially if there was a video conference during class. Fortunately, the three courses taken and rated by these students did not carry out video conferencing, so the noisy environment did not interfere with the course.

Regarding internet signals during online lectures, students answered good signals (31.6\%), signals were sometimes good, sometimes disturbed (64.7\%) and signals were too bad (3.7\%). A student answered that the signal was not strong and the environment was too noisy as well, and thus, the student could not give respond in class. The student also added:

"Satu-satunya hal yg menurut saya kurang baik adalah koneksi di daerah rumah saya sendiri. Terkadang saya harus ke rumah saudara atau teman untuk urusan perkuliahan yg penting atau untuk menghadiri rapat yg penting."

'The only thing that I considered not good is the connection in my own home area. Sometimes I have to go to relative's home or friends for joining lectures or to attend important online meetings.'

Furthermore, regarding communication and response between lecturers and students, there were several answers. Student answers were as follows: Communication with lecturers was clear and I could respond $(89.7 \%)$, clear but I could not respond $(8.8 \%)$, unclear but I could respond $(0.7 \%)$, and unclear and I could not respond $(0.7 \%)$. The ability to respond, besides depending on internet quota, was also affected by their environment. One student wrote,

"Penulisan kanji dalam buku kotak cukup memotivasi, namun saya cukup kesulitan melakukannya dikarenakan saya di rumah juga bekerja untuk membantu orang tua sehingga waktu perkuliahan saya banyak yg terpotong."

'Writing Kanji in the practice book was motivating, but I had some difficulties doing it because at home I also had to worked helping my parents, and so, my time was cut off a lot.'

In this case, it was the situation of the environment that caused students unable to actively participate.

A lecture was a process able to motivate students or vice versa. When students were asked about the part of the courses that they felt motivating, the answers varied as follows. First, the interactions done in WhatsApp Group helped both the lecturer and the students.

"Interaksi yang dilakukan pada whatsapp grup sudah membuat suasana kelas lebih hidup" "The interactions done in the WhatsApp group had successfully made the online class more enjoyable.'
"Lewat grup WA yang responsif walaupun dalam masa kuliah online, tetap bisa bertanya dengan leluasa kepada dosen dan tetap bisa seperti kelas yang biasanya." "The WhatsApp group was responsive during the online classes, made it possible for us to freely ask the lecturer about everything just like how it was in the offline classes'

"Keterlibatan secara aktif baik dari dosen maupun mahasiswa sehingga mata kuliah dapat berjalan seperti biasanya (kelas luring)" "The active interaction between the lecturer and the students made this course conducted just like the usual (although it was all online)'

Second, the quick feedback, and no differences in pattern between the previous offline meetings and the current online class motivated students as well.

"Ketika berinteraksi dengan dosen, baik ketika dikoreksi latihannya maupun dikoreksi kus dan pr. Sangat membantu agar tahu letak kesalahan di mana. Terima kasih sensei." "Interaction with the lecturer, both while correcting the lessons and in receiving the feedback of the assignments and quiz. It is very helpful to know which part of the answer was wrong. Thank you, sensei / teacher'

"Feedback dari para dosen yang membuat mahasisea terus semangat dalam menjalankan mata kuliah" "The feedback from lecturers made the students keep motivated in joining the class'

"Menurut saya mata kuliah ini sudah sangat baik. Dosen dan mahasiswa terlibat dalam tanya jawab didalam forum, tugas2 dikerjakan seperti biasa, latihan2 juga bisa dilakukan seperti biasa sama seperti pembelajaran di kelas."

'I think this class is already good. Both the lecturer and students were involved in discussions, the assignments were done as usual, so as the lessons, all were the same with how it was previously done in the offline class'

Third, enthusiasm from the lecturer could motivate the students as well. Deadline in assignment trained them to do the task on-time, despite the teaching was done remotely. Also, by providing materials to be accessible anytime, it helped students who want to review the lesson. This might help them who had internet problem as well.

"Menurut saya sistem pembelajarannya lumayan efektif meskipun dalam proses pjj, dosen juga sangat antusias dalam mengajar sehingga secara tidak langsung ikut memotivasi mahasiswa/i"

'I think the learning system was effective, despite the process was done online. The lecturer was also enthusiast in teaching. So, indirectly, it motivated us, the students.'

"Mungkin yang membuat saya merasa termotivasi adalah dengan mengumpulkan tugas dan mengerjakan kuis. Ketika sensei memberi deadline tugas, saya merasa harus segera melaksanakannya karena tidak ingin mepet dengan deadline. Sedangkan untuk kuis, meskipun saya sebenarnya bisa mencontek buku ketika mengerjakan, 
saya memilih tidak karena pasti hasilnya percuma karena itu bukan murni jawaban saya sendiri. Jadi mata kuliah ini memotivasi saya untuk berusaha menjadi pribadi yang disiplin dan jujur."

'Maybe I was really motivated because of submitting assignments and doing quizzes. When the lecturer gave us the deadline, I felt like I had to do that because I did not want to rush when it was closer to deadline. As for the quiz, although I actually could cheat by looking up the books while doing it, I chose not to do that. Because the results would be of waste, and it would not be my own answers. So, this course motivated me to become a diligent and an honest student.'

"Kuliah menggunakan metode yang efektif dan netral sehingga mahasiswa dengan koneksi buruk pun dapat mengikuti kuliah"

'The method was neutral so that students with bad internet connection were still able to join the class'

"Karena materinya dapat diakses kapanpun tanpa batas waktu dan kita bisa melihat review daribtugas yang kita kerjakan,dalam pemberian tugas matkul ini memberikan waktu yang cukup bagi mahasiswa untuk mengerjakan tugas tersebut"

'Because the materials were accessible anytime without due time and we could reviewed our homework. There were plenty of time given for students to finish the homework'

Regarding things that had better be improved, some opinions were as follows. Although no video conference was conducted, students felt it is important to check whether everyone had been present. The aim was to make sure that when a student was asked to give opinion, the person could answer immediately, saved more time than those who got up late or had not been online yet. Also, internet signal was another problem.

"Bagi saya mungkin sang dosen hanya perlu mengabsen para mahasiswa secara manual setiap jam pembelajaran dimulai, dimana para mahasiswa yang sudah online harus menyatakan kehadiran mereka misal dengan menulis "saya hadir" agar sang dosen bisa mengerti, dan supaya tidak ada kasus lagi dimana ada mahasiswa yang tidak merespon perintah dari dosen karena mereka belum online, ketiduran, dll."

'For me, maybe the lecturer just needs to evaluate students manually before starting the online class. For example, online students had to state their participation by wrote "I am here" so that the lecturer understood, and so that in the next time, there are no cases where students were not responsive in doing tasks given by lecturers because they had not been online, fell asleep, etc.'

"Menurut saya sudah cukup baik, hanya saja terkadang sinyal yg jelek menjadi gangguan"
'I think this class was already good. Just the internet signal was sometimes not good, and that was the only interruption'

Also, doing discussion in WhatsApp group had tendency to make older chat got piled up by the newer one. This might be troublesome for some students to do review.

"Menurut saya via WA bagus hanya saja ketika saya ingin mendengarkan penjelasan sensei sudah ketimbun"

'I think doing class via WhatsApp is good. But sometimes, when I want to hear the explanation, the lecturer's (voice note) had already been piled up by the newer chat'

In the following question, if there were any materials difficult to understand/comprehend, most students answered there were no problems. However, some stated that similar grammar or similar Kanji were difficult. Sometimes, although the lecturer already explained the differences, it was still difficult for them.

"Menurut saya tidak ada karena sensei sudah menjelaskan dengan detail. Jadi tergantung masing-masing mahasiswa jika ada yg belum faham tentang materinya."

'I think there were no problems since the lecturer already explained everything in detail. So, it is up to the student personal ability if some materials are not understandable'

"Ada, yaitu adanya beberapa kanji yang memiliki cara baca atau makna yang sama"

'Yes, there were. Some Kanji with the same reading method or the same meaning'

"Adanya persamaan makna antara satu pola kalimat dengan pola kalimat yang lain, terkadang sulit untuk membedakannya."

'The similar meaning between one grammar to the other. Sometimes it is difficult to distinguish the differences.'

"Ada beberala materi yang memang dari segi pola kalimat hampir sama. Meskipun dosen sudah menjelaskan beberapa kali, tetapi terkadang kata2nya sulit dimengerti,misalnya materi seide dan bakari ni"

'Yes, there were some similar grammars. Although the lecturer already tried to explain it multiple times, sometimes the explanation itself was difficult. For example, the sei de and bakari ni'

For other answers/ opinions, some were stated below. Some students viewed that basically they prefer offline class, and the problem was not in the materials. Other answered no problems happened, but another said that the house condition made them unable to participate.

"Menurut saya bukan materinya yang susah dimengerti tapi karena perkuliahan jarak jauh dan saya rasa sistem belajar online kurang cocok bagi saya pribadi" 
'I think it is not difficult to understand the materials. But, the classes were done online, and this kind of delivering method were not compatible with me'

"Tidak ada, semua bahan yang di berikan oleh Dosen telah jelas dan mudah di pahami, semua sesuai jadwal dan berjalan seperti kelas ofline ketika di kampus." 'Nothing. All the materials we got from the lecturer were already clear and understandable, everything executed as scheduled, and done just like how we usually did it on campus/ offline class'

\section{"tidak dapat mengikuti kliah karena kondisi rumah"}

'I could not participate in course due to my home condition'

Some lecturers used video conferencing as a substitute for face to face interactions. However, student internet connections were often unstable when using video conferencing applications, such as Zoom (Atmojo \& Nugroho, 2020; Windhiyana, 2020). Video conferencing applications, depends to the number of participants, required a lot of internet quota in a short amount of time, and a strong and stable internet connection too. Those requirements were not all fulfilled by all students. The connection strength was certainly influenced by the location of the students, and the provider they were using. By taking this as consideration, in this study, as a substitute for Zoom, the course discussions were conducted via WhatsApp group. The lecturer-student interaction via WhatsApp did not experience significant problems, except for students who did not fully participate from the start due to some reasons, e.g. woke up late, had sickness, ran out of internet quota, immediate power outage at home, and so on. Although some students did not state their reasons, but those were the most frequently excuses they said during the courses. In addition, before the pandemic, WhatsApp had been proven effective in learning, out-of-class communication, and enhancing student's motivation (Amry, 2014; Hershkovitz, Elhija, $\&$ Zedan, 2019). Thus, this study results confirm those findings.

Actually, when student's internet connection was unstable, the lecturer could do a number of things to solve this. First, repeat the explanation as done via Zoom (Windhiyana, 2020). Second, provide leeway for students by providing downloadable material after the class ended, and giving students the opportunity to ask questions outside of class hours, but still in office hours. The condition of student's home, internet connection, and physical health certainly greatly affect the student ability to attend classes on schedule. At times like this, lecturers were required to be more flexible but firm in meeting student attendance, to ensure all students got the same material.

Knight (2020) outlines 4 keys to successful distance learning, namely that participant 1) have the technical ability to operate the platform that was used specifically for lectures; 2) develop basic competencies for evaluation; 3 ) shows ongoing and ongoing interactions, and 4) participates in collaboration with other participants. The existence of the WhatsApp group had directly confirmed the point, and as evidenced in online classes, the main aspect was the occurrence of balanced communication between lecturers and students, as well as commented from one student on other students' answers. One-way communication, that was from lecturers only, would not be able to maintain student motivation to actively participate. González- Lloret (2020) also emphasizes that interaction is the main key to develop language skills in a foreign language class and the existence of learning output (oral and written) and the presence of interaction, will greatly motivate learners to continue improve their abilities.

In addition, students found Power-Point to be very helpful for them to understand the material (Moorhouse, 2020). In the three courses (Japanese Kanji and grammars), Power-Point materials was available for students according to the meeting schedule, and accessible through the university platform. Accessing new material that was available when class starts, as long as there was no time limit for accessing, actually also made it easy for students who had internet difficulties, or cannot attend lectures on that day. They could access Power Point when there was time, and could learn it themselves according to their vacant schedule.

Furthermore, the use of social media as a medium for language learning was quite good for student progress (Reinhardt, 2020). In this case, WhatsApp as one of the popular social media used in Indonesia really helped to facilitate a quick and real-time interaction between class participants. In general, classroom communication using WhatsApp had proven to be effective, because lecturers could immediately give feedback to students one by one, so that the existence of each individual student was recognized (Guillén, Sawin, \& Avineri, 2020).

In the end, similar to any practical online class, there were a number of things that should be considered. Mainly, whether the main needs in the form of communication modes (interpretive, presentational, interpersonal) and the ability of students to hear, read, speak, and write were met or not (Gacs, Goetler, \& Spasova, 2020). Regardless of this, Gacs, Goetler, and Spasnova state that online lessons will be vulnerable to be filled with too much writing. For those who were new to online lectures, class design preparation could be vulnerable to many problems, because lecturers were not familiar with the platform. They also state, in this case, communicating openly with students was the best solution, so that lecturers could adapt well according to the needs of students. In addition, class rules should be 
explained as clearly as possible from the start of the class transition from face-to-face to online. Students and lecturers cannot do face-to-face meeting. So, as the compensation, interactions must exist, and lecturers must be visible to them (can be in the form of online text messages, or video conferencing). In this study, the clear communication and quick response in lecturestudent interaction through WhatsApp group were proven effective as the substitute for video conferencing.

\section{CONCLUSION}

Through the results of this study, it is concluded that the student voices have expressed one of the most important aspect of online lectures, guarantying twoway communication between lecturers and students. As long as this aspect is fulfilled, then they would be motivated and enthusiastically joined the class. In addition, students expect rapid communication to be responded to, not limited to certain platforms. Communication, in this case does not have to be faceto-face, even a short message can be an appropriate compensation. So, video conferencing that is often used in online lectures, can actually be an optional choice, if we consider the internet quota and signal strength from the students' side. Although WhatsApp is used, it is certainly possible, that other similar platforms can provide more or less similar results. However, the limitation of class, and the demotivating factors pointed out by the students showed that regardless of any positive feedbacks available, improvement is a must. Positive feedbacks define points that need to be maintained for the next classes, and the negative ones showed additional things need to be changed, improved, or not used.

\section{REFERENCES}

Amry, A. B. (2014). The impact of WhatsApp mobile social learning on the achievement and attitudes of female students. European Scientific Journal, 10(22), 116-134.

Atmojo, A. E. P., \& Nugroho, A. (2020). EFL classes must go online! Teaching activities and challenges during COVID-19 Pandemic in Indonesia. Register Journal, 13(1), 49-76.

BNPB. (2020). Keputusan Kepala Badan Nasional Penanggulangan Bencana Nomor 13.A Tahun 2020. Retrieved from https://www.docdroid.net /file/download/ZQfEj4d/sk-ka-no-13-a-tahun2020 .pdf

Cakrawati, L. M. (2017). Students' perceptions on the use of online learning platforms in EFL classroom. English Language Teaching and Technology Journal, 1(1), 22-30.

Gacs, A., Goertler, S., \& Spasova, S. (2020). Planned online language education versus crisis-prompted online language teaching. Foreign Language Annals, 53, 380-392.

González- Lloret, M. (2020). Collaborative tasks for online language teaching. Foreign Language Annals, 53(2), 260-269.

Guillén, G., Sawin, T., \& Avineri, N. (2020). Zooming out of the crisis: Language and human collaboration. Foreign Language Annals, 53(2), 320-328

Hershkovitz, A., Elhija, M. A., \& Zedan, D. (2019). WhatsApp is the message: Out-of-class communication, student-teacher relationship, and classroom environment. Journal of Information Technology Education, 18, 63-95.

Knight, S. W. (2020). Establishing professional online communities for world language educators. Foreign Language Annals, 53, 298-305.

Marker, M. (2003). Indigenous voice, community, and epistemic violence: The ethnographer's" interests" and what" interests" the ethnographer. International Journal of Qualitative Studies in Education, 16(3), 361-375.

Mazzei, L. A. (2009). Introduction: The limit of voice. In A.Y. Jackson and L.A. Mazzei (Eds), Voice-in qualitative inquiry: Challenging conventional, interpretive, and critical conceptions in qualitative research (pp. 1-14). New York: Routledge.

Mendikbud. (2020). Surat Edaran Mendikbud: Pembelajaran secara Daring dan Bekerja dari Rumah dalam Rangka Pencegahan Penyebaran Corona Virus Disease (COVID-19). Retrieved from http://kemdikbud.go.id/main/files/download lc5d9f0ec9ff40c6

Moorhouse, B. L. (2020). Adaptations to a face-to-face initial teacher education course 'forced'online due to the COVID-19 pandemic. Journal of Education for Teaching, 1-3.

Oreg, S. (2003). Resistance to change: Developing an individual differences measure. Journal of applied psychology, 88(4), 680-693.

Reinhardt, J. (2020). Metaphors for social mediaenhanced foreign language teaching and learning. Foreign Language Annals, 53, 234-242.

Wanberg, C. R., \& Banas, J. T. (2000). Predictors and outcomes of openness to changes in a reorganizing 
workplace. Journal of applied psychology, 85(1), $132-142$.
Windhiyana, E. (2020). Dampak Covid-19 terhadap kegiatan pembelajaran online di sebuah perguruan tinggi kristen di Indonesia. Perspektif Ilmu Pendidikan, 34(1), 1-8. 